This is the author's final, peer-reviewed manuscript as accepted for publication. The publisher-formatted version may be available through the publisher's web site or your institution's library.

\title{
Multistage filtration process for efficient treatment of oil-field produced water using ceramic membranes
}

Mehrdad Ebrahimi, Zoltan Kovacs, Maren Schneider, Peter Mund, Peter Bolduan, Peter Czermak

\section{How to cite this manuscript}

If you make reference to this version of the manuscript, use the following information:

Ebrahimi, M., Kovacs, Z., Schneider, M., Mund, P., Bolduan, P., \& Czermak, P. (2012). Multistage filtration process for efficient treatment of oil-field produced water using ceramic membranes. Retrieved from http://krex.ksu.edu

\section{Published Version Information}

Citation: Ebrahimi, M., Kovacs, Z., Schneider, M., Mund, P., Bolduan, P., \& Czermak, P. (2012). Multistage filtration process for efficient treatment of oil-field produced water using ceramic membranes. Desalination and Water Treatment, 42(1-3), 17-23.

Copyright: ( Desalination Publications.

Digital Object Identifier (DOI): doi: 10.1080/19443994.2012.682964

Publisher's Link: http://www.tandfonline.com/doi/abs/10.1080/19443994.2012.682964

This item was retrieved from the K-State Research Exchange (K-REx), the institutional repository of Kansas State University. K-REx is available at http://krex.ksu.edu 


\title{
Multistage filtration process for efficient treatment of oil- field produced water using ceramic membranes
}

\author{
Mehrdad Ebrahimi*, Zoltan Kovacs*, Maren Schneider ${ }^{*}$, Peter Mund ${ }^{* *}$, Peter Bolduan ${ }^{* *}$, \\ Peter Czermak ${ }^{*}{ }^{* *}$ \\ *Institute of Bioprocess Engineering and Pharmaceutical Technology (IBPT), University of Applied \\ Sciences Mittelhessen, Wiesenstrasse 14, 35390 Giessen, Germany \\ Tel. +49 (0)641 309 2552; email: mehrdad.ebrahimi@kmub.thm.de \\ ** Atech Innovations GmbH, Gladbeck, Germany \\ Kansas State University, Dept. of Chemical Engineering, Manhattan KS, USA
}

\begin{abstract}
Oil and gas industries generate large amounts of wastewater as a byproduct in both onshore and offshore production operations. This wastewater is commonly referred to as "produced water" (PW). PW is very difficult to treat and its characteristics changes by well to well. Treatment of this produced water could improve the economic viability of these oil and gas fields and lead to a new source of water for beneficial use. This work describes a research project that evaluated the multistage treatment process of oilfield produced water generated from tank dewatering with different ceramic membranes. The investigations focuse on the characterization of permeate flux using various ceramic microfiltration (MF), ultrafiltration (UF) and nanofiltration (NF) membranes as potential techniques for efficient treatment of tank dewatering produced water (TDPW). Results for average flux rates, flux degradation, removal of organic substances (measured as TOC) and inorganic substances (measured as the electrical conductivity (EC)) and oil removal efficiency are shown.
\end{abstract}

Keywords: Ceramic membrane; Oilfield; Produced water treatment; Membrane fouling, Flux degradation; Oil removal

\section{INTRODUCTION}

Oilfield produced water is a term used in the oil industry to describe the water that is produced along with the oil and/or gas [1]. Produced water (PW) is the largest waste stream generated in oil and gas industries. It may include water from the reservoir, water previously injected into the formation, and any chemicals added during the production processes. The volume of produced water is continuously increasing, as long as the wells are getting older and new wells are perforated. Every year, about 14 to 18 billion barrels of produced water are generated from on-shore oil and gas production in the U.S. alone [2]. In some cases, the volume of water increases so fast that it can reach more than $50 \%$ of the total liquid production in a couple of years and up to $90 \%$ at the mature stage [3]. Due to the increasing volume of waste all over the world in the current decade, the outcome and effect of discharging produced water on the environment has lately become a significant issue of environmental concern [4]. Major pollutant in oilfield wastewater is oil which may range between 100 and $1000 \mathrm{mg} \mathrm{l}^{-1}$ or still higher depending on the efficiency of demulsification and nature of crude oil [5]. Another matter of great concern is the high salinity in oilfield produced water, because it poses difficulties for treatment processes. Produced waters typically contain high levels of dissolved solids [6]. Currently PW is typically disposed in injection wells as waste or for pressure maintenance of the reservoir. Treatment of this produced water could improve the economic viability of these oil and gas fields and lead to a new source of water for beneficial use [7]. Beneficial use of produced water can increase water supply and reduce the volume of concentrate brine for disposal [8]. Successful treatment of complex produced water generally requires a series of operations be used to remove different contaminants [9].

In order to meet environmental regulations as well as reuse and recycling of produced water, many researchers have focused on treating oily saline produced water [4]. In general, produced water treatment is approached through deoiling and de-mineralizing before its 
disposal or utilization. Various technologies and methods exist for treatment of oil field produced water [10]. Most oil removal technologies cannot achieve the separation required to meet water quality standards [11] for beneficial use by meeting potable and irrigation water quality standards [12].

The use of membrane processes for treatment of produced water has several advantages over many of the traditional separation techniques [13]. During the last two decades significant advances have been made in the development and application of microfiltration (MF), ultrafiltration (UF), nanofiltration (NF) and reverse osmosis (RO) processes. Some of the significant advantages are: (a) The membrane is a positive barrier to rejected components, (b) no addition of chemicals is required, (c) membranes can be used in process to allow recycling of selected waste streams and (d) membrane equipment has a smaller footprint, (e) energy costs are often lower and (f) the plant can be highly automated [7].

The use of ceramic membranes for treatment of wastewaters is growing in certain applications and above all in those filtration processes where polymeric membranes cannot be applied [14]. Advantages of ceramic membranes include higher fluxes, due to their higher porosity and more hydrophilic surface, compared to organic membranes. The resistance of ceramic membranes against mechanical, chemical and thermal stress allows a better recovery of membrane performance [15]. The weakness of ceramic membranes arises mainly from the manufacturing process, which makes it difficult to achieve a reproducible final product quality [16]. This along with the intrinsically brittle character of ceramic membranes makes them always more expensive than polymeric membrane systems. The study presented here focuses on the efficient development of single and combined treatment processes for tank dewatering produced water and different prepared oily model solutions using different ceramic membranes. The process consists of a pre-treatment step using cross-flow MF and a single or multistage post-treatment step utilizing cross-flow UF and NF.

\subsection{Oilfield wastewater characteristics}

Knowledge of the constituents of specific produced water is needed for regulatory compliance and for selecting management/disposal options such as secondary recovery and disposal [2]. The physical and chemical properties of produced water vary considerably depending on the geographic location of the field, the geologic formation, and the type of hydrocarbon product being produced. Produced water properties and volume also vary throughout the lifetime of a reservoir [17]. The basic components of produced water can be grouped into the following main categories: oil, heavy metals, radionuclides, production chemicals, salt, and dissolved oxygen. Produced water may contain high levels of chlorides - as much as 10 times more than seawater [18]. The salinity of produced water is due to dissolved sodium and chloride and is less contributed by calcium, magnesium, and potassium. Salt concentration of produced water may vary from a few parts per million (ppm) to about 300,000 $\mathrm{mg} \mathrm{l}^{-1}$ [19].

\section{EXPERIMENTAL}

\subsection{Multistage filtration system}

Multistage cross-flow membrane filtration equipment with MF-, UF-, and/or NF- systems in parallel was conducted using a stirred tank (ST) with the membrane modules (Fig. 1). Each membrane system is comprised of the centrifugal pump, the ceramic membrane unit, the feed, permeate, retentate streams (maximum operating pressure and temperature of 3 bar and $90^{\circ} \mathrm{C}$ respectively) and the back flushing unit with a maximum operating pressure of $10 \mathrm{bar}$. At regular time intervals, back flushing was executed pumping a mixture of permeate or water and air, reversely. The mean pressure at the membrane was determined by measuring the pressure before and after the membrane and averaging these values; this pressure is reported as the trans-membrane pressure (TMP). All filtration experiments were carried out at $60^{\circ} \mathrm{C}$. 

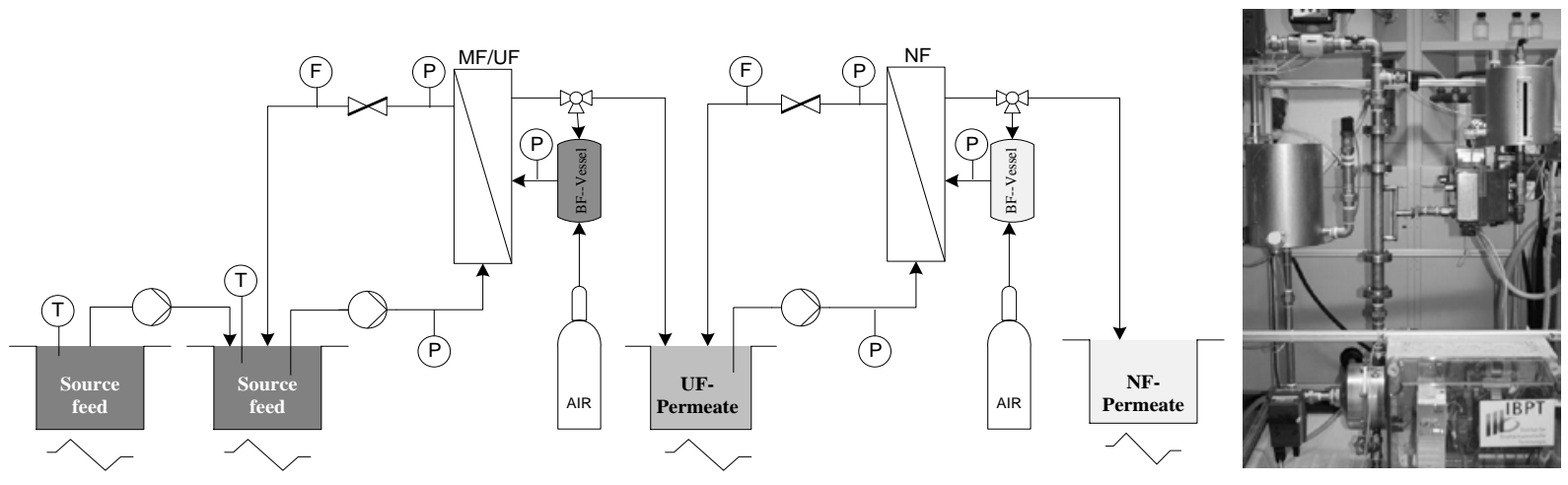

Fig.1. Schematic of the laboratory scale cross-flow filtration system

\subsection{Studied ceramic membranes}

The ceramic membranes used in this study are tubular and consist of a porous support material (generally $\alpha$-alumina), a minimum of one layer of decreasing pore diameter and a separating layer ( $\alpha$-alumina, zirconia, etc.) covering the internal surface of the tube. In Table 1 , the properties of the ceramic membranes used in this investigation are listed.

Table 1

Characteristics of ceramic membranes used in this investigation.

\begin{tabular}{lllll}
\hline Membrane & $\mathrm{MF}-\mathrm{Al}_{2} \mathrm{O}_{3}$ & $\mathrm{UF}-\mathrm{TiO}_{2}$ & $\mathrm{NF}-\mathrm{TiO}_{2}$ & $\mathrm{NF}-\mathrm{TiO}_{2}$ \\
\hline Material & $\mathrm{Al}_{2} \mathrm{O}_{3} / \mathrm{Al}_{2} \mathrm{O}_{3}$ & $\mathrm{TiO}_{2} / \mathrm{Al}_{2} \mathrm{O}_{3}$ & $\mathrm{TiO}_{2} / \mathrm{TiO}_{2}$ & $\mathrm{TiO}_{2} / \mathrm{Al}_{2} \mathrm{O}_{3}$ \\
Cut-off & $0.1 \mu \mathrm{m}, 0.2 \mu \mathrm{m}$ & $0.05 \mu \mathrm{m}, 20 \mathrm{kDa}$ & $1000 \mathrm{Da}$ & $750 \mathrm{Da}$ \\
pH & $0-14$ & $0-14$ & $0-14$ & $0-14$ \\
Temp. Max. $\left[{ }^{\circ} \mathrm{C}\right]$ & 121 & 121 & 150 & 120 \\
\hline
\end{tabular}

\subsection{Cleaning of ceramic membranes}

Fouling through suspended oil and grease, particles and colloids and salts is one of the most common problems and a major operational factor encountered in produced water treatment applications of membranes [20]. To reduce membrane fouling, the effect of chemical cleaning and back flushing on ceramic membranes was investigated. Chemicals used for membrane cleaning were lye solutions $(1 \%$ (w/w) $\mathrm{NaOH}$ solution, Ultrasil P3-14, Ultrasil P3-10 for 30 to $60 \mathrm{~min}$ ), dissolved in distilled water. Back flushing is a method applied commonly to remove a layer of retained material [21]. Here, the flow was reversed for 3-8 sec. to flush the membrane pores from permeate and, thus, to release material retained in the membrane pores.

\subsection{Model oily wastewater}

Different model solutions (MS) were prepared in a heated stirred tank through mixing waste oil (5\%-30\% (w/w)) with distilled water for $30 \mathrm{~min}$ at $60^{\circ} \mathrm{C}$ (Tab. 2). To simulate a primary process of separation from oil, the mixture was unstirred for 30 min to clarify. The free oil was recovered and pumped back to the waste oil tank. The model oily wastewater showed a uniform yellowish color. 


\subsection{Studied PW characteristics}

Samples of tank dewatering produced water (TDPW) were obtained from German BP AG, Oil Refinery Emsland, Lingen. The concentration range of components in TDPW used in this study is given in Tab. 2 .

Table 2

Characteristics of MS and TDPW used in this investigation

\begin{tabular}{ccccccc}
\hline Parameter & $\begin{array}{c}\text { Dispersed oil } \\
\left(\mathrm{mg} \mathrm{l}^{-1}\right)\end{array}$ & $\begin{array}{c}\mathrm{pH} \\
\text { value }\end{array}$ & $\begin{array}{c}\text { EC } \\
\left(\mu \mathrm{cm}^{-1}\right)\end{array}$ & $\begin{array}{c}\text { TOC } \\
\left(\mathrm{mg} \mathrm{l}^{-1}\right)\end{array}$ & $\begin{array}{c}\text { Iron } \\
\left(\mathrm{mg} \mathrm{l}^{-1}\right)\end{array}$ & $\begin{array}{c}\text { Zinc } \\
\left(\mathrm{mg} \mathrm{l}^{-1}\right)\end{array}$ \\
\hline MS & $32-180$ & $7.0-7.8$ & $162-70,600$ & $23-1025$ & N.A. & N.A. \\
TDPW & $10-1000$ & $6.0-8.0$ & $20,000-80,000$ & $200-2000$ & 66 & 0.55 \\
\hline
\end{tabular}

\subsection{Analytical measurement}

The analysis of oil in water was executed using an oil-in-water analyzer based on UV fluorescence (TD-500D, Nordatec GmbH, Bremerhaven/Germany). TOC concentrations were determined using the TOC cell test and a photometer (Photolab S6, WTW, Weilheim/Germany). Using a multi-range conductivity meter (HI 9033, Hanna Instruments, Kehl am Rhein, Germany), the electric conductivity in feed and permeate were determined.

\section{RESULTS AND DISCUSSION}

Selecting a set of optimum operation conditions is an important issue in membrane filtration which influence the filtration flux, the quality of permeate and the fouling extent of membrane [22]. The permeate flow rate depends on surface area of membrane, dissolved-solids concentration in the feed stream, cross-flow velocity and transmembrane pressure (TMP) applied across the membrane. In this study, the effectiveness of the single and combined MF, UF and/or NF processes for treatment of tank dewatering produced water and different model solutions was evaluated in terms of the permeate flux rates and degradation, fouling behavior, oil and TOC removal efficiency and conductivity reduction.

\subsection{The behavior of membrane fouling}

Fouling of membrane can be defined as irreversible deposition of material onto or into the membrane, causing flux decline. In general, increasing flux leads to an increase in polarization and fouling, which limits the flux [23, 24, 25]. In this study, the permeate flux was calculated from $\mathrm{F}=\mathrm{V} /(\mathrm{A} * \mathrm{t})$, where $F$ is the liquid flux across the membrane $\left(\mathrm{l} \mathrm{h}^{-1} \mathrm{~m}^{-2}\right), A$ the membrane surface area in contact with the liquid $\left(\mathrm{m}^{2}\right)$ and $V$ the volume of the permeate collected (l) during time $t(\mathrm{~h})$.

The measured flux decline during the cross-flow micro- and ultratfiltration processes of TDPW is shown in Fig. 2a for $0.2 \mu \mathrm{m}$ and $0.05 \mu \mathrm{m}$ ceramic membranes respectively. At the beginning, permeation fluxes declined gradually until an invariable flux value (after 60 min of running time) was obtained. In this case, MF and UF membranes were able to provide a total oil removal percentage of $90 \%$ and $99 \%$ respectively at 0.5 bar TMP and a feed water temperature of $60^{\circ} \mathrm{C}$. The TOC removal percentage for MF and UF membrane were about $24 \%$ and $73 \%$, respectively. These results indicate that membrane fouling of different membranes used produce different fouling situations. 

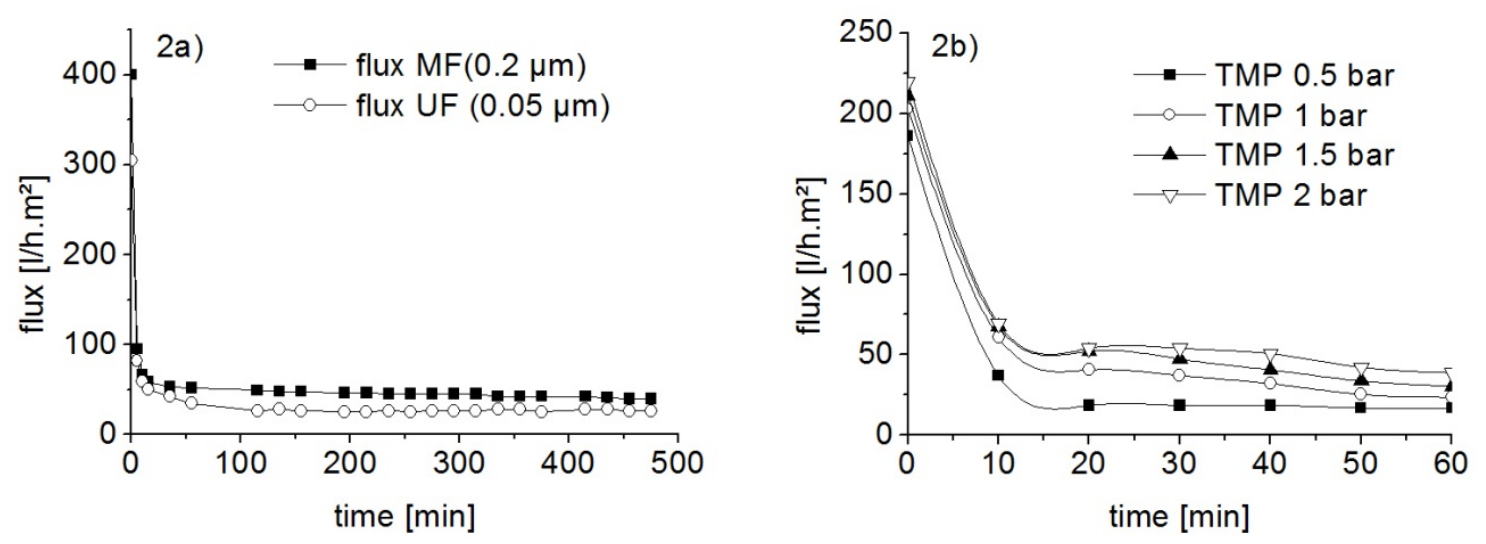

Fig. 2. a) Flux for a $0.2 \mu \mathrm{m}$ ceramic MF and a $0.05 \mu \mathrm{m}$ ceramic UF membrane and tank dewatering produced water; TMP: 0.5 bar; temperature $60^{\circ} \mathrm{C}$. b) Flux at different TMP $(0.5$, 1.0, 1.5, 2.0 bar) for a $0.05 \mu \mathrm{m}$ ceramic UF membrane and tank dewatering produced water, temperature $60^{\circ} \mathrm{C}$.

\subsection{Effect of TMP}

In this work, the TMP, as one of the most important operating condition factor, was investigated. For almost all experiments, results showed an increasing flux for higher TMP values over the whole process time (Fig. 2b). The effect of TMP on filtration flux within the operation time of MF and UF membranes shows that the initial and pseudo-steady flux increased with higher pressure but the increase extent decrease, which was similar to the results obtained in former studies [10, 26, 27].

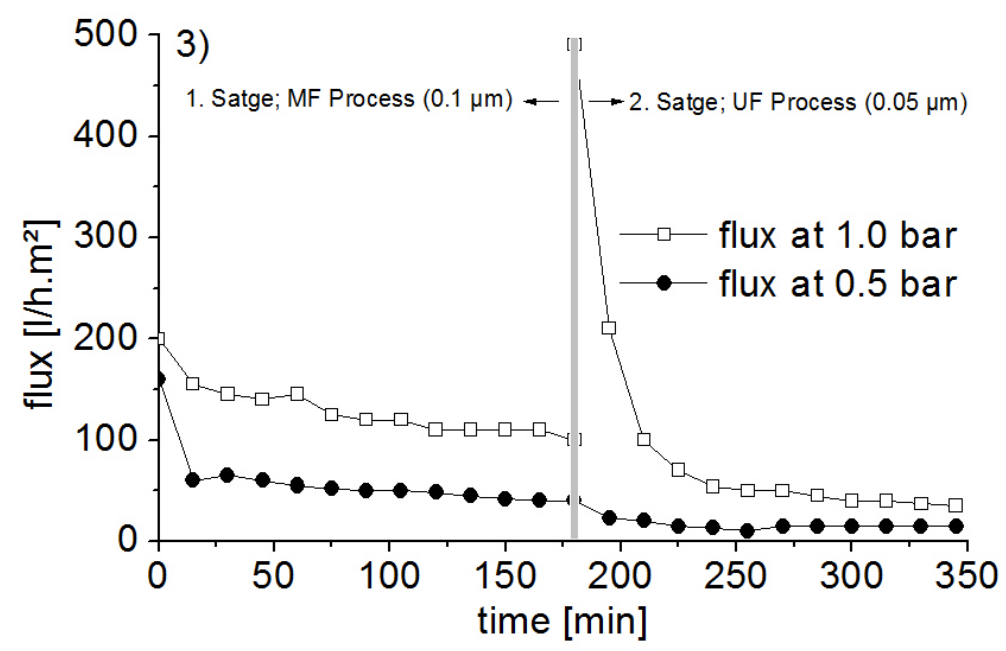

Fig. 3. Flux at different TMP (0.5 and $1.0 \mathrm{bar})$ for different ceramic membranes MF $(0.1 \mu \mathrm{m})$ followed by UF $(0.05 \mu \mathrm{m})$ and TDPW, temperature $60^{\circ} \mathrm{C}$.

Representative for a number of experiments, Fig. 3 gives the fouling curves versus time for different ceramic membranes $\operatorname{MF}(0.1 \mu \mathrm{m})$, UF $(0.05 \mu \mathrm{m}))$ during the treatment of TDPW at different TMP $(0.5,1.0$ bar) in a 2-stage filtration process. The micro- and ultrafiltration processes ran for 180 min continually. A major decay in flux during the initial 50 to $60 \mathrm{~min}$ is indicated. After $60 \mathrm{~min}$, the data show solely a decent decline in flux performance. The 
permeate flow rate increases from $100 \mathrm{l} \mathrm{h}^{-1} \mathrm{~m}^{-2}$ at 0.5 bar to $200 \mathrm{l} \mathrm{h}^{-1} \mathrm{~m}^{-2}$ at 1.0 bar TMP caused an increase of $50 \%$ on the permeate flux in the case of MF $(0.1 \mu \mathrm{m})$ process and from $20 \mathrm{l} \mathrm{h}^{-1} \mathrm{~m}^{-2}$ to $50 \mathrm{l} \mathrm{h}^{-1} \mathrm{~m}^{-2}$ in the case of UF $(0.05 \mu \mathrm{m})$ process. In summary, a positive effect of the pressure on the permeate flux was observed for the investigated membranes. However, higher TMP requires more electrical power, thus increasing overall energy consumption.

\subsection{Effect of feed characteristics}

In this work, the effect of feed concentration on the permeate quality (regarding the oil, TOC and salt content) and permeate flux of single and combined 3-stage processes was investigated, using different model solutions and TDPW.

Effect of different initial oil concentrations Here, the effects of different feed initial oil concentrations on permeate flux, removal of oil and TOC is investigated. As shown in Fig. 4a and $5 \mathrm{~b}$ the performed investigations indicated that there was a gradual decline of the permeate flux along with increasing oil concentration of the feed. Fig. 4a shows the comparison of flux degradation of a $1 \mathrm{kD}$ NF ceramic membrane for different concentrations of prepared model solutions $(10 \%$ and $20 \%(\mathrm{w} / \mathrm{w}))$ within 60 min of operation time. In case of model solution with an initial oil concentration of $10 \%(\mathrm{w} / \mathrm{w})$, the permeate flux declined from initially 110 to $58 \mathrm{l} \mathrm{h}^{-1} \mathrm{~m}^{-2}$ after 1 hour running time.
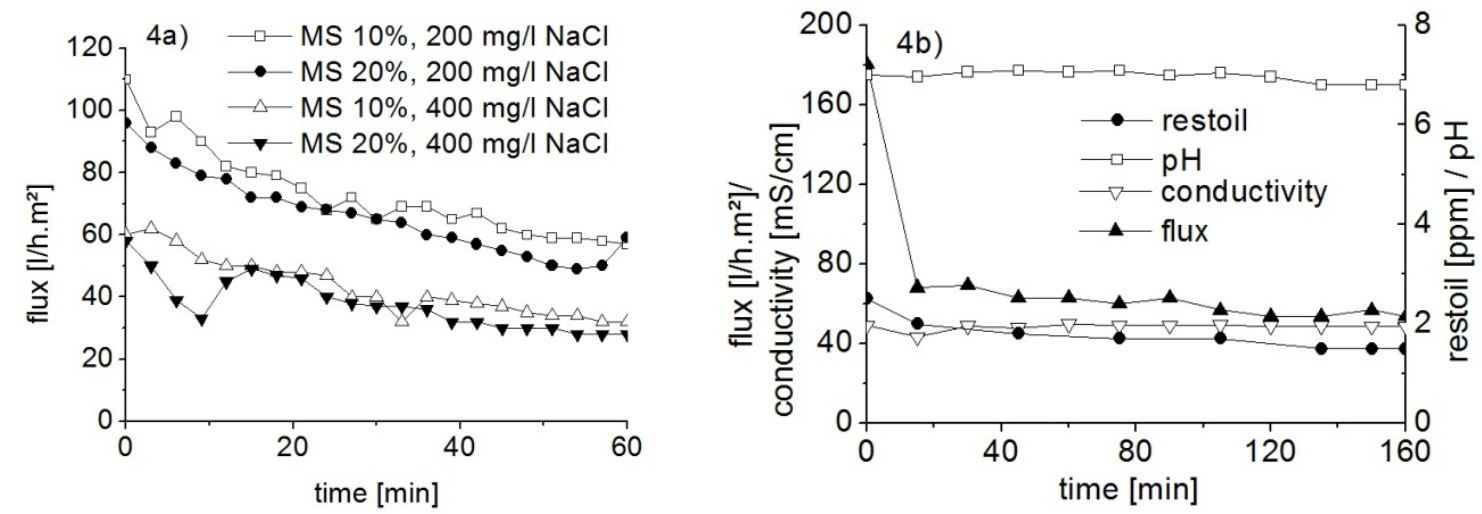

Fig. 4. a) Comparison of flux for a $1 \mathrm{kDa}$ ceramic NF membrane using different model solutions (10\% and 20\% (w/w), initial NaCl-Concentrations: $200 \mathrm{mg} \mathrm{l}^{-1}$ and $400 \mathrm{mg} \mathrm{l}^{-1}$ ), TMP $1.0 \mathrm{bar}$, temperature $60^{\circ} \mathrm{C}$ and b) for a $1 \mathrm{kDa}$ ceramic NF membrane, model solution (5\% (w/w)), initial NaCl-Concentration: $30 \mathrm{~g} \mathrm{l}^{-1}$; TMP 1.0 bar; temperature $60^{\circ} \mathrm{C}$.
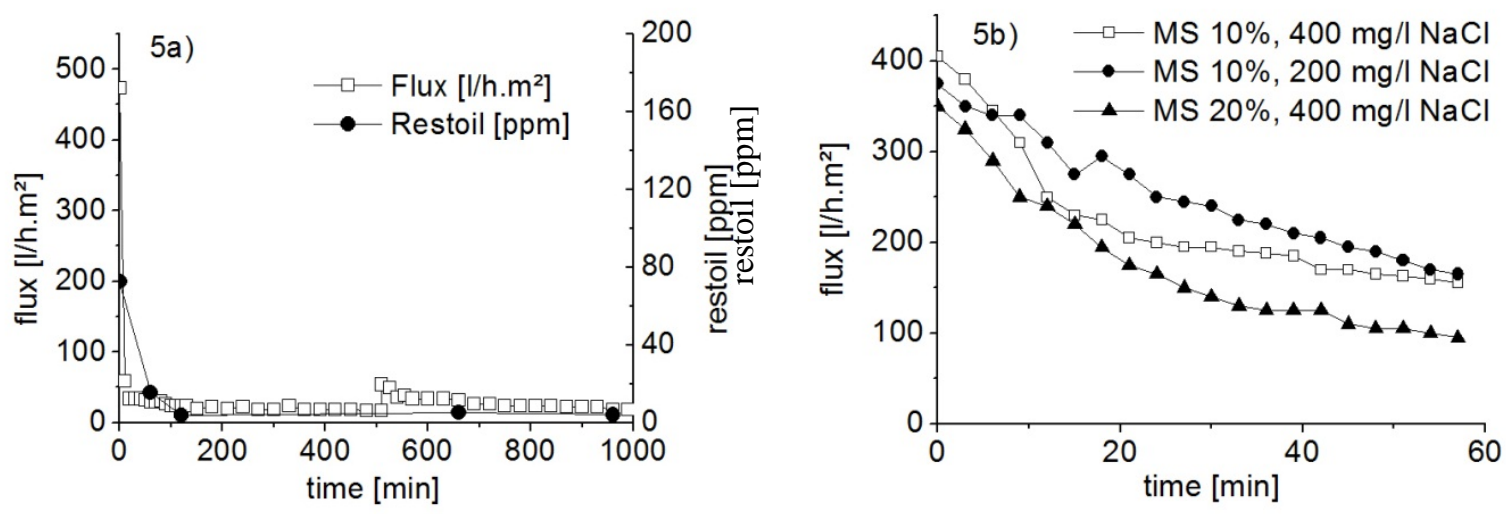

Fig. 5. a) Flux and oil removal efficiency for a $0.2 \mu \mathrm{m}$ ceramic MF membrane, model solution (oil wastewater 10\% (w/w), initial NaCl-Concentration: $250 \mathrm{~g} \mathrm{l}^{-1}$ ); TMP 1.0 bar; temperature 
$60^{\circ} \mathrm{C}$. b) Flux for a $20 \mathrm{kDa}$ UF, model solutions (oil wastewater $10 \%$ and $20 \%(\mathrm{w} / \mathrm{w})$ ), initial NaCl-Concentrations: $200 \mathrm{mg} \mathrm{l}^{-1}$ and $400 \mathrm{mg} \mathrm{l}^{-1}$, TMP $1.0 \mathrm{bar}$, temperature $60^{\circ} \mathrm{C}$.

Using model solution (oil concentration: 20\% (w/w)), a decrease in the permeate flux from initially 60 to $33 \mathrm{l} \mathrm{h}^{-1} \mathrm{~m}^{-2}$ after a running time of $1 \mathrm{~h}$ was observed. This is due to the fact that membrane performance strongly depends upon the feed stream. The high flux in combination with a strong chemical composition of the feed causes much more rapid fouling. In Fig. 4b the change of permeate flux, conductivity and $\mathrm{pH}$ in permeate samples is shown as a function of time for a $1 \mathrm{kD}$ NF ceramic membrane using model solution (10\% (w/w)) and initial $\mathrm{NaCl}$ concentration $30 \mathrm{~g} \mathrm{l}^{-1}$. Oil removal percentage for NF membrane was about $44 \%$.

Fig. 5a shows the single treatment performance utilizing $0.2 \mu \mathrm{m}$ MF to process model solution with $10 \%(\mathrm{w} / \mathrm{w})$ initial oil concentration. The degree of efficiency of the MF process was assessed in terms of the permeate flux rate, fouling characteristics, and the degree of oil removed. The change in permeate flux rate after $10 \mathrm{~min}$ of running time at a constant TMP of $1.0 \mathrm{bar}$ and a temperature of $60^{\circ} \mathrm{C}$, average percentages of feed concentration and removal for microfiltrated oil measured in steady state after 16 hours are shown in Table 3.

Table 3

Summary of the results derived from a $0.2 \mu \mathrm{m}$ ceramic MF membrane using model solution $10 \%\left(\mathrm{w} / \mathrm{w}\right.$ ) as feed solution; initial NaCl-Concentration: $250 \mathrm{~g} \mathrm{l}^{-1}$; TMP 1.0 bar at $60^{\circ} \mathrm{C}$.

\begin{tabular}{lllllll}
\hline $\begin{array}{l}\text { Membrane } \\
\text { Cut-off }\end{array}$ & $\begin{array}{l}\text { Flux at } \mathrm{t}_{0} \\
\mathrm{l} \mathrm{h}^{-1} \mathrm{~m}^{-2}\end{array}$ & $\begin{array}{l}\text { Flux at } \mathrm{t}_{10 \mathrm{~min}} \\
\mathrm{l} \mathrm{h}^{-1} \mathrm{~m}^{-2}\end{array}$ & $\begin{array}{l}\mathrm{C}_{\text {oil }} \\
(\mathrm{ppm})\end{array}$ & $\begin{array}{l}\text { Oil Re. } \\
(\%)\end{array}$ & $\begin{array}{l}\mathrm{EC}_{\text {Feed }} \\
\left(\mu \mathrm{S} \mathrm{cm} \mathrm{c}^{-1}\right)\end{array}$ & $\begin{array}{l}\mathrm{EC}_{\text {Reductio }} \\
(\%)\end{array}$ \\
\hline $0.2 \mu \mathrm{m}$ & 473 & 59 & 199.5 & 93.7 & 70600 & 13 \\
\hline
\end{tabular}

Effect of initial salinity ( $\mathrm{NaCl}$ ). Oil and grease are the constituents of produced water that receive the most attention in both onshore and offshore operations, while salt content (expressed as salinity, conductivity, or total dissolved solids) is also a primary constituent of concern in onshore operations [2]. Produced water includes largely salts and oil hydrocarbons which may be toxic to environment [28]. Salinity refers to the amount of total dissolved salts (TDS) in water and is frequently measured by electrical conductivity (EC), because ions dissolved in water conduct electricity and actual TDS analyses are expensive to conduct. EC levels of more than $3,000 \mu \mathrm{S} \mathrm{cm}^{-1}$ are considered saline [29].

In the presented investigations, the salinity of model solutions was adjusted by adding $\mathrm{NaCl}$ in different concentrations (200 mg l $\mathrm{m}^{-1}, 400 \mathrm{mg} \mathrm{l}^{-1}, 30 \mathrm{~g} \mathrm{l}^{-1}$ and $250 \mathrm{~g} \mathrm{l}^{-1}$ ). In all experiments, different samples of permeate and concentrate flows were taken to determine the salinity, expressed as electric conductivity. Figures $4 \mathrm{a}$ and $5 \mathrm{~b}$ show that the permeate flux of both UF $(20 \mathrm{kD})$ and NF (1 kD) ceramic membrane decreases with increase in salinity of the used model solution from $200 \mathrm{mg} \mathrm{l}^{-1}$ to $400 \mathrm{mg} \mathrm{l}^{-1}$ at constant TMP of $1.0 \mathrm{bar}$. Data presented in Table 4 are representative of the broad range of experimental results for oil and TOC removal efficiency and reduction of electrical conductivity obtained from 2-stage (MF followed by UF) and 3-stage filtration processes (MF followed by UF/NF) using different ceramic membranes and feed solutions respectively. 
Table 4

Summary of results derived from $0.1 \mu \mathrm{m}, 0.05 \mu \mathrm{m}$ and 1000 Da ceramic membranes using different feed solutions after filtration across the membranes. TMP, 0.5 and 1.0 bar; temperature, $60^{\circ} \mathrm{C}$

\begin{tabular}{|c|c|c|c|c|c|c|}
\hline \multicolumn{7}{|c|}{ 2-stage membrane process (UF/NF) } \\
\hline $\begin{array}{l}\text { Membrane } \\
\text { Cut-off }\end{array}$ & Feed & $\begin{array}{l}\text { TMP } \\
\text { (bar) }\end{array}$ & $\begin{array}{l}\text { Oil-Re. } \\
\text { (\%) }\end{array}$ & $\begin{array}{l}\text { TOC-Re. } \\
\text { (\%) }\end{array}$ & $\begin{array}{l}\text { EC }_{\text {Feed }} \\
\left(\mu \mathrm{S} \mathrm{cm}^{-1}\right)\end{array}$ & $\begin{array}{l}\mathrm{EC}_{\text {Reduction }} \\
(\%)\end{array}$ \\
\hline & MS, $10 \% \mathrm{w} / \mathrm{w}$ & - & - & - & 264 & - \\
\hline UF $0.05 \mu \mathrm{m}$ & MS & 1.0 & 96 & 75 & 58 & 78 \\
\hline \multirow[t]{2}{*}{ NF $1000 \mathrm{Da}$} & Permeate from UF & 1.0 & 27 & 7,4 & 46 & 20,3 \\
\hline & TDPW & - & - & - & 39600 & - \\
\hline UF $0.05 \mu \mathrm{m}$ & TDPW & 1.0 & $>99$ & 13.6 & 27400 & 30 \\
\hline NF $1000 \mathrm{Da}$ & Permeate from UF & 1.0 & $>99$ & 49.8 & 26000 & 5.1 \\
\hline \multicolumn{7}{|c|}{ 3-stage membrane process (MF/UF/NF) } \\
\hline $\begin{array}{l}\text { Membrane } \\
\text { Cut-off }\end{array}$ & Feed & $\begin{array}{l}\text { TMP } \\
\text { (bar) }\end{array}$ & $\begin{array}{l}\text { Oil-Re. } \\
(\%)\end{array}$ & $\begin{array}{l}\text { TOC-Re. } \\
(\%)\end{array}$ & $\begin{array}{l}\mathrm{EC}_{\text {Feed }} \\
(\mu \mathrm{S} / \mathrm{cm})\end{array}$ & $\begin{array}{l}\mathrm{EC}_{\text {Reduction }} \\
(\%)\end{array}$ \\
\hline-- & MS, $10 \% \mathrm{w} / \mathrm{w}$ & - & - & - & 213 & - \\
\hline MF $0.1 \mu \mathrm{m}$ & MS & 1.0 & 45 & 3 & 169 & 21 \\
\hline UF $0.05 \mu \mathrm{m}$ & Permeate from MF & 1.0 & 28 & 20 & 169 & 0 \\
\hline \multirow[t]{2}{*}{ NF $1000 \mathrm{Da}$} & Permeate from UF & 1.0 & 58 & NA & 168 & 0.6 \\
\hline & TDPW & - & - & - & 44900 & - \\
\hline MF $0.1 \mu \mathrm{m}$ & TDPW & 0.5 & 93 & 15 & 44300 & 1.3 \\
\hline UF $0.05 \mu \mathrm{m}$ & Permeate from MF & 0.5 & 66 & 32 & 44300 & 0 \\
\hline \multirow[t]{2}{*}{ NF $1000 \mathrm{Da}$} & Permeate from UF & 0.5 & 80 & 48 & 25400 & 43 \\
\hline & TDPW & - & - & - & 44400 & - \\
\hline MF $0.1 \mu \mathrm{m}$ & TDPW & 1.0 & 95 & 26 & 43200 & 2.7 \\
\hline UF $0.05 \mu \mathrm{m}$ & Permeate from MF & 1.0 & 20 & 8.3 & 41400 & 4.1 \\
\hline NF $1000 \mathrm{Da}$ & Permeate from UF & 1.0 & 50 & 60 & 20200 & 51 \\
\hline
\end{tabular}

EC: electric conductivity; Re.: removal; NA: not available

\section{CONCLUSIONS}

In this work a study was performed for the treatment of oilfield produced water and model solutions using different ceramic membranes to examine the effects of feed oil, salt content and transmembrane pressure on the permeate flux rates and degradation, fouling behavior, oil and TOC removal efficiency and conductivity reduction. The following conclusions were obtained: (1) the investigated membrane processes (single and combined MF, UF and NF) are 
excellent techniques to remove oil from oilfield produced water and prepared oily model solution, (2) the permeate flux declined faster with increasing feed concentration (regarding the oil content and salinity) and smaller membrane pore sizes, (3) the increase in TMP from 0.5 to 2.0 bar, resulted in a increase of permeate flow rate and subsequent increase in convective transport of oil droplets to the membrane, (4) total removal percentage of oil content ranged from $45-93 \%$ for MF and $80-99.5 \%$ for UF followed by NF, while TOC removal ranged from 3-26\% for MF and 13-60\% for UF followed by NF, (5) to clean ceramic membranes fouled by oilfield produced water, back flushing was assessed (in terms of flux recovery) as more effective than chemical cleaning using various lye solutions, as it was reported previously [10, 26, 27, 30].

\section{ACKNOWLEDGEMENTS}

The authors gratefully thank the Federal Ministry of Education and Research Germany for the financial support (FKZ: 1731X07). Furthermore the authors would like to thank Dipl.-Ing. Martin Müller, German BP AG, Oil Refinery Emsland, Lingen, for providing us with the tank dewatering produced water.

\section{REFERENCES}

[1] L. Leiming, K. Eliseeva, V. Eliseev, O. A. Bustos et al, Well Treatment Fluids Prepared with Oilfield Produced Water, SPE (Society of Petroleum Engineers) 2009, Annual Technical Conference and Exhibition, New Orleans, Louisiana, USA, 4-7 October 2009, SPE 124212.

[2] J.A. Veil, M.G. Puder, D. Elcock, Jr. Redweick and J. Robert, A White Paper Describing Produced Water From Production of Crude Oil, Natural Gas, and Coal Bed Methane, Argonne National Laboratory, January 2004, Report availble at: http://www.evs.anl.gov/pub/doc/ProducedWatersWP0401.pdf

[3] O. Rambeau, R. Morales de Lafond, P. Baldoni, J.P. Gosselin and J.C. Baccou, Low salt petroleum produced water reuse: a farming alternative outside the food chain, Wat. Sci. Technol., 50 (2004) 139-147.

[4] F. Ahmadun, A. Pendashteh, L.C. Abdullah, D.R. Awang Biak, S.S. Madaeni and Z.Z. Abidin, Review of technologies for oil and gas produced water treatment, Journal of Hazardous Materials, 170 (2009) 530-551.

[5] Rupesh M. Bande, B. Prasad, I.M. Mishra and Kailas L. Wasewar, Oil field effluent water treatment for safe disposal by electroflotation, Chem. Eng. J., 137(2008) 503509.

[6] J.C. Campos, R.M.H. Borges, A.M. Oliveira Filho, R. Nobrega and G.L. Sant'Anna Jr., Oilfield wastewater treatment by combined microfiltration and biological processes, Wat. Res., 36 (2002) 95-104.

[7] S. Mondal and S. Ranil Wickramasinghe, Produced water treatment by nanofiltration and reverse osmosis membranes, J. Membrane Sci., 322 (2008) 162-170.

[8] P. Xu, J.E. Drewes and D. Heil, Beneficial use of co-produced water through membrane treatment: technical-economic assessment, Desal., 225 (2008) 139-155

[9] L. Dallbauman and T. Sirivedin, Reclamation of produced water for beneficial use, Sep. Sci. Technol., 40 (2005) 185-200.

[10] M. Ebrahimi, D. Willershausen, K. Shams Ashaghi, L. Engel, L. Placido, P. Mund, P. Bolduan and P. Czermak, Investigations on the use of different ceramic membranes for efficient oil-field produced water treatment, Desal., 250 (2010) 991-996. 
[11] J. Mueller, Y. Cen and R.H. Davis, Crossflow microfiltration of oily water, J. Membrane Sci., 129 (1997) 221-235.

[12] Y.K. Kharaka, L.Y.C. Leong, G. Doran and G.N. Breit (1998) Can produced water be reclaimed? - Experience with the Placerita oil field, California, in Sublette, K.L., ed., Environmental Issues in Petroleum Exploration, Production and Refining-Proceedings $5^{\text {th }}$ International Petroleum Environmental Conference, Albuquerque, New Mexico, October 20-23, (1998) 25

[13] M. Takht Ravanchi, T. Kaghazchia and A. Kargarib, Application of membrane separation processes in petrochemical industry: a review, Desal., 235 (2009) 199-244.

[14] J.M. Benito, M.J. Sánchez, P. Pena and M.A. Rodríguez, Development of a new high porosity ceramic membrane for the treatment of bilge water, Desal., 214 (2007) 91101.

[15] T. Melin, R. Rautenbach, Membranverfahren. Springer Verlag (2003).

[16] N. Laitinen, Development of a ceramic membrane filtration equipment and its applicability for different wastewaters, Diss. Lappeenranta University of Technology, Lappeenranta 2002.

[17] C.E. Clark and J.A. Veil, Produced Water Volumes and Management Practices Sep. 2009, Argonne, National Laboratory, ANL/EVS/R-09/1, Report availble at: http://www.osti.gov/bridge.

[18] L. Sumi, Produced water from oil and gas production, Presentation at the 2005 People's Oil and Gas Summit Farmington, New Mexico, October 28, 2005, Report availble at: http://www.saveballona.org/gasoilfields/Produced-H2O.pdf.

[19] R.P.M.W. Jacobs, R.O.H. Grant, J. Kwant, J.M. Marquenie and E. Mentzer, The composition of produced water from Shell operated oil and gas production in the North Sea, in: J.P. Ray, F.R. Engelhardt (Eds.), Produced Water: Technological/ Environmental Issues and Solutions, Plenum Publishing Corp., New York, (1992) 1322.

[20] S. Ebrahim, Cleaning and regeneration of membranes in desalination and wastewater applications: state-of-the-art, Desal., 96 (1994) 225-238.

[21] H. Peng, A.Y. Tremblay and D.E. Veinot, The use of backflushed coalescing microfiltration as a pretreatment for the ultrafiltration of bilge water, Desal., 181 (2005) 109-120.

[22] R.R. Bhave, Inorganic membranes synthesis, characteristics and applications, Van Nostrand Reinhold, New York, 1991.

[23] S.H.D. Silalahi and T. Leiknes, Cleaning strategies in ceramic microfiltration membranes fouled by oil and particulate matter in produced water, Desal., 236 (2009) 160-169.

[24] V. Chen, H. Li, D. Li, S. Tan and H.B. Petrus, Cleaning strategies for membrane fouled with protein mixtures, Desal., 200 (2006) 198-200.

[25] G. Gésan-Guiziou, E. Boyaval and G. Daufin, Critical stability conditions in crossflow microfiltration of skimmed milk: transition to reversible deposition, J. Membrane Sci., 158 (1999) 211-222.

[26] P. Czermak and M. Ebrahimi, Multiphase Cross-Flow Filtration Process for Efficient Treatment of Oil-Field Produced Water Using Ceramic Membranes, Proceedings $7^{\text {th }}$ Produced Water Workshop, paper 5, 29th - 30th April 2009, Aberdeen, UK. 
[27] M. Ebrahimi, K. Shams Ashaghi, L. Engel, D. Willershausen, P. Mund, P. Bolduan and P. Czermak, Characterization and application of different ceramic membranes for the oil-field produced water treatment, Desal., 246 (2009) 160-167.

[28] M. Çakmakce, N. Kayaalp and I. Koyuncu, Desalination of produced water from oil production fields by membrane processes, Desal., 222 (2008) 176-186.

[29] ALL Consulting, 2003, "Handbook on Coal Bed Methane Produced Water: Management and Beneficial Use Alternatives," prepared by ALL Consulting for the Ground Water Protection Research Foundation, U.S. Department of Energy, and U.S. Bureau of Land Management.

[30] K. Shams Ashaghi, M. Ebrahimi and P. Czermak. Ceramic Ultra- and Nanofiltration Membranes for Oilfield Produced Water Treatment: A Mini Review, Open Env. J., 1 (2007) 1-8. 